\title{
American Justice: Prosecutorial Discretion in the United States Criminal Justice System ${ }^{1}$
}

\author{
Justiça Americana: discricionariedade persecutória \\ no sistema judicial nos Estados Unidos
}

Amie Ely

\begin{abstract}
As the only American attorneys charged with seeking justice, prosecutors play an important role and carry a unique burden in the justice system. In the United States, prosecutors are administrators of justice, representing a sovereign whose interest "is not that it shall win a case, but that justice shall be done." This article describes the discretion afforded to American prosecutors-which includes deciding whether to initiate cases against defendants, dismiss charges, enter into plea agreements, or go to trial-and outlines the ethical rules and cases that guide and govern the exercise of that discretion.
\end{abstract}

Keywords: Prosecutor. Discretion. Ethics. Plea bargaining.

\section{Resumo}

Como os únicos advogados americanos acusados de buscar justiça, os promotores desempenham um papel importante e carregam um fardo único no sistema de justiça. Nos Estados Unidos, os promotores são administradores de justiça, representando um soberano cujo interesse "não é que ele ganhe um caso, mas que a justiça seja feita." Este artigo descreve o poder discricionário oferecido aos promotores americanos - o que inclui decidir sobre a possibilidade de se iniciar processos contra réus, destituir acusações, firmar acordos de culpa ou ir a julgamento - e esboça as regras éticas e os casos que orientam e governam o exercício desse poder discricionário.

Palavras-chave: Promotor. Discricionariedade. Ética. Negociação de pleito.

This piece is modified and updated from Amie N. Ely, Note: Prosecutorial Discretion as an Ethical Necessity: The Ashcroft Memorandum's Curtailment of the Prosecutor's Duty to "Seek Justice," 90 Cornell L. Rev. 237 (2004). Thanks to the Cornell Law Review for granting permission to republish, and to NAAG Fellow Constance Patterson for her assistance.

Doctor of Law-JD. Director, NAGTRI Center for Ethics \& Public Integrity, National Association of Attorneys General; former Assistant United States Attorney in the Southern District of New York (2008-2015). Nova Iorque - Estados Unidos. E-mail: aely@naag.org 


\section{Introduction}

As the only American attorneys charged with seeking justice, ${ }^{2}$ prosecutors play an important role and carry a unique burden in the justice system. ${ }^{3}$ In the United States, prosecutors are administrators of justice, ${ }^{4}$ representing a sovereign whose interest "is not that it shall win a case, but that justice shall be done." ${ }^{5}$ As Robert $H$. Jackson explained to a group of U.S. Attorneys over sixty years ago, "the citizen's safety lies in the prosecutor who tempers zeal with human kindness, who seeks truth and not victims, who serves the law and not factional purposes, and who approaches his task with humility."6

When Director of the Federal Bureau of Investigation James Comey $^{8}$ was the U.S. Attorney for the Southern District of New York, he would tell every new prosecutor: "Don't you ever say something you don't completely believe. I'm not even talking about shades of gray. If

2 Berger v. United States, 295 U.S. 78, 88 (1935).

3 See, e.g., Peter J. Henning, Prosecutorial Misconduct and Constitutional Remedies, 77 Wash. U. L.Q. 713, 727 (1999) The ethical rules that govern the legal profession single out prosecutors as the only participants who must adhere to a special duty beyond that of representing zealously their "client." This higher duty has been variously phrased to require the prosecutor "to seek justice, not merely to convict," and "to serve as a minister of justice and not simply [as] an advocate." (citations omitted) (second alteration in original). But see William H. Simon, Ethical Discretion in Lawyering, 101 Harv. L. Rev. 1083, 1090-91 (1988) (proposing that other attorneys should also "seek justice," adopting "a style of ethical judgment for private lawyers analogous to that familiarly associated with judges or prosecutors").

4 ABA Standards Relating to the Administration of Criminal Justice, The Prosecution Function 3-1.2(b) (1992) [hereinafter ABA Standards], available at http://www.abanet.org/crimjust/ standards/pfunc toc.html (last visited Sept. 2, 2016).

5 See Berger, 295 U.S. at 88.

6 Robert H. Jackson, The Federal Prosecutor, 31 Am. Inst. Crim. L. \& Criminology 3, 6 (1940-41).

7 See Al Kamen, One Show Turkey and a Lot of Fowl, Wash. Post, Dec. 10, 2003, at A29; Siobhan Roth \& Vanessa Blum, Summoned to Main Justice at Time of Exodus, Scrutiny, N.Y. L.J., Oct. 7, 2003 , at 1. Comey has a "reputation[] for placing high value on prosecutorial integrity." Gary Fields \& Greg Hitt, Ashcroft Gives Up Role in Inquiry into CIA Leak, Wall St. J., Dec. 31, 2003, at A4.

8 See Al Kamen, One Show Turkey and a Lot of Fowl, Wash. Post, Dec. 10, 2003, at A29; Siobhan Roth \& Vanessa Blum, Summoned to Main Justice at Time of Exodus, Scrutiny, N.Y. L.J., Oct. 7, 2003 , at 1. Comey has a "reputation[] for placing high value on prosecutorial integrity." Gary Fields \& Greg Hitt, Ashcroft Gives Up Role in Inquiry into CIA Leak, Wall St. J., Dec. 31, 2003, at A4. 
you don't 100 percent believe it, don't you dare say it. That's why being a prosecutor is so great: You don't have to make arguments you don't believe in." $\mathrm{He}$ told law students interning at the Southern District of New York in 2003 that he could "hire smart all day," but that intelligence alone was not enough. ${ }^{10}$ Because prosecutors have the ability to ruin lives, he explained, he looked for people who could exercise this power with discretion and sensitivity. ${ }^{11}$

This Article examines the various ethical considerations that guide prosecutors in the United States in exercising their sizeable discretion. ${ }^{12}$ Part A surveys prosecutorial discretion as conceived by the common law, courts, and commentators. Part B examines prosecutorial discretion as described by the U.S. Attorneys' Manual, the American Bar Association's Standards for Criminal Justice Relating to the Prosecution Function, and the American Bar Association's Model Rules of Professional Conduct.

\section{Prosecutorial Discretion in the United States}

In some cases, the application of the criminal laws to a particular individual, though supported by probable cause, is unwarranted in light of the individual's lack of culpability. The prosecutor must recognize when the circumstances of a person's situation are such that prosecution would "do more harm than good."13

9 Chris Smith, Mr. Comey Goes to Washington, N.Y. Mag., Oct. 20, 2003, available at http://www. newyorkmetro.com/nymetro/news/politics/n 9353/index.html (last visited Mar. 19, 2004).

10 James Comey, Address at U.S. Attorney's Office for the Southern District of New York Luncheon (July 22, 2003) (attended by the author).

11 See id.

12 For a critique of the dangers of too much discretion, see James Vorenberg, Decent Restraint of Prosecutorial Power, 94 Harv. L. Rev. 1521, 1523 (1981), which describes the scope of prosecutorial power at that time as "both inconsistent with the fair and effective administration of justice and unnecessary to serve the purposes offered to justify it."

13 Harry I. Subin et al., Federal Criminal Practice: Prosecution and Defense 5.3(a) (1992) (citing Wayne R. LaFave \& Jerold H. Israel, Criminal Procedure 13.1(c) (1985)). 


\subsection{Prosecutorial Discretion Under the Common Law}

The duty to seek justice is the "long-understood role of the prosecutor in every jurisdiction"14 in the United States and is realized by prosecutors with "the power to criminally charge." 15 Prosecutors' authority to charge is governed by the Constitution, statutes, and court opinions. While American prosecutors have exclusive authority to prosecute, they are not generally required to do so in every case. ${ }^{16}$ Prosecutorial discretion is not unlimited, but rather is constrained by "norms of equality and rationality that are difficult to enforce in the courts." ${ }^{17}$ Violations of these norms include discriminatory prosecution and complete nonenforcement of a category of crime. ${ }^{18}$ Problems of proof often defeat defendants' charges of discriminatory prosecution, however, and victims have difficulty obtaining standing to compel prosecution or proving that a prosecutor has engaged in total non-enforcement of a particular crime. ${ }^{19}$

Thus, prosecutors face many occasions to exercise their discretion ${ }^{20}$ and have traditionally enjoyed great deference in wielding that discretion. In fact, prosecutors often determine which persons should be investigated; often choose the methods of investigation and what information to seek as evidence; decide whom to charge with what offense; whom to use as witnesses; and whether (and on what terms) to enter into plea bargains and grant immunity. ${ }^{21}$

When deciding whether to prosecute a person, prosecutors traditionally weighed factors such as the role he played in and

United States ex rel. Green v. Peters, Nos. 93 C 7300, 93 C 5671, 93 C 5672, 93 C 5673, 1994 WL 8258, at 6 n.3 (N.D. III. Jan. 8, 1994).

15 People v. O’Neill, 379 N.Y.S.2d 244, 249 (1975).

16 See Abraham S. Goldstein, The Passive Judiciary: Prosecutorial Discretion and the Guilty Plea 9 (1981) (citation omitted).

17 Id. at 11.

18 See id. at 9-10.

19 id.

20 Young v. United States ex rel. Vuitton et Fils S.A. 481 U.S. 787, 813 (1987).

21 Id. at 807. 
his motivations for entering into a criminal venture, as well as his background, criminal history, and the specific circumstances surrounding the violation. ${ }^{22}$ Government interests also traditionally played a role in prosecutors' charging decisions. For example, the willingness of the accused to assist the prosecutor in building cases against others could lead to dismissal or reduction of the charges if the governmental interest in successfully prosecuting others outweighed the interest in convicting the accused of the most serious possible charge. ${ }^{23}$ Other factors, such as the impact of the offense on the victim and the community, the relative importance of the case, and the public attitude about the prosecution could also affect the prosecutor's charging decision. ${ }^{24}$

In colonial days and through the 1800s a "prosecutor had unlimited discretion to enter a nolle prosequi ${ }^{25}$ without any court involvement." 26 The nolle was inherited from sixteenth century England, where the Attorney General would use it to rein in a private prosecutor's frivolous or unsubstantiated charges, as well as meritorious charges that interfered with a state prosecution. ${ }^{27}$

The nearest analogue to the nolle in the contemporary federal system is Federal Rule of Criminal Procedure 48(a), which permits the Attorney General to dismiss an indictment, information, or complaint by leave of the trial judge, who often requires that the government provide some rationale for the dismissal request. ${ }^{28}$ Some commentators and judges, however, suggest that courts have no power to force continued

\footnotetext{
See Subin et al., supra note 13, 5.3(a), 5.4(a).

See id. 5.3(c) (citation omitted).

Id

"To be unwilling to prosecute."

State v. Mucci, 782 N.E.2d 133, 139 (Ohio Ct. App. 2002) (explaining further that "the legislators and courts of this state and the federal government have acted to take this unlimited postindictment discretion away from the prosecutor"); see also In re Richards, 213 F.3d 773, 782 (3d Cir. 2000) ("Absent a controlling statute or rule to the contrary, this power [to enter a nolle prosequi] resides solely in the prosecutor's hands until the impanelment and swearing of a jury."); cf. State $v$. Sonneland, 494 P.2d 469, 471 (Wash. 1972) (holding that a statute abrogated the discretion to dismiss a prosecution that a prosecuting attorney traditionally enjoyed at common law.)

27 See Goldstein, supra note 16, at 12.

28 See Goldstein at 17-19.
} 
prosecution of cases that prosecutors do not believe warrant prosecution - including cases where the prosecutor does not believe she can prove the charges at trial. ${ }^{29}$ This suggests a functional return to the traditional discretion afforded by nolle prosequi.

2.2 Modern Standards and Rules Governing Prosecutorial Discretion

\subsubsection{U.S. Attorneys' Manual Section 9-27: Principles of Federal Prosecution}

Guidelines promulgated by the Department of Justice in the U.S. Attorneys' Manual (Manual) suggest that prosecutors enjoy "broad discretion in such areas as initiating or foregoing prosecutions, selecting or recommending specific charges, and terminating prosecutions by accepting guilty pleas ...."30 The Manual offers suggestions meant to "provid[e] guidance rather than to mandate[e] results" 31 and is intended to assure the public and individual defendants that prosecutors will make decisions "rationally and objectively on the merits of each case." 32 Recognizing that the system's success hinges upon "the character, integrity, sensitivity, and competence of those men and women who are selected to represent the public interest in the Federal criminal justice

29 See id. at 20.

30 U.S. Dep't of Justice, U.S. Attorneys' Manual 9-27.110 cmt, available at https://www.justice. gov/usam/usam-9-27000-principles-federal-prosecution\#9-27.110 (updated July 2009). The Manual discusses the factors prosecutors should consider in deciding whether to prosecute a case:"The manner in which Federal prosecutors exercise their decision-making authority has far-reaching implications, both in terms of justice and effectiveness in law enforcement and in terms of the consequences for individual citizens. A determination to prosecute represents a policy judgment that the fundamental interests of society require the application of the criminal laws to a particular set of circumstances - recognizing both that serious violations of Federal law must be prosecuted, and that prosecution entails profound consequences for the accused and the family of the accused whether or not a conviction ultimately results. Other prosecutorial decisions can be equally significant. Decisions, for example, regarding the specific charges to be brought, or concerning plea dispositions, effectively determine the range of sanctions that may be imposed for criminal conduct."

$31 \quad 9-27.001$

32 Id. 
process," ${ }^{33}$ the Manual explains that "the prosecutor has wide latitude in determining when, whom, how, and even whether to prosecute for apparent violations of Federal criminal law."34

The Manual further explains that all federal prosecutors should "be guided by a general statement of principles that summarizes appropriate considerations to be weighed, and desirable practices to be followed, in discharging their prosecutorial responsibilities." ${ }^{35}$ Also, "it is not intended that reference to these principles will require a particular prosecutorial decision in any given case," but rather that the Manual will help prosecutors determine how best to exercise their authority while performing their duties. ${ }^{36}$ Toward this end, the Manual offers federal prosecutors guidelines to help them determine whether to file charges against an accused.

Probable cause that the accused committed the charged crime is an absolute prerequisite to filing charges. ${ }^{37}$ Federal prosecutors should consider several additional factors when determining whether to initiate prosecution, including whether a substantial federal interest is served by prosecuting, whether another jurisdiction would effectively prosecute, and whether an "adequate non-criminal alternative to prosecution" is available. ${ }^{38}$

Considerations relevant to ensuring that an adequate federal interest exists to prosecute include: priorities of federal law enforcement; the deterrent effects of prosecuting the accused; the nature and seriousness of the crime; the criminal history of the accused, his individual

33 Id.

$34 \quad$ Id. 9-27.110 cmt.

35 Id. (emphasis added). Furthermore, although these principles deal with the specific situations indicated, they should be read in the broader context of the basic responsibilities of federal prosecutors: making certain that the general purposes of the criminal law-assurance of warranted punishment, deterrence of further criminal conduct, protection of the public from dangerous offenders, and rehabilitation of offenders - are adequately met, while making certain also that the rights of individuals are scrupulously protected.

$36 \quad$ Id. $9-27.120 \mathrm{cmt}$.

37 Id. $9-27.200 \mathrm{cmt}$.

38 Id. 9-27.220. 
culpability and his willingness to cooperate in other investigations or prosecutions; and "the probable sentence or other consequences if the person is convicted." 39

To assess whether another jurisdiction can effectively prosecute the accused, a prosecutor should consider whether the other jurisdiction has a strong interest in prosecuting, its willingness to effectively prosecute, and the likely sentence it will give the accuser if he is convicted. ${ }^{40} \mathrm{~A}$ prosecutor may decline to pursue criminal charges where noncriminal sanctions adequately reflect the culpability of the accused and are likely to be imposed, and the effect of the noncriminal disposition does not militate against federal law enforcement interests. ${ }^{41}$ These noncriminal dispositions include subjecting the defendant to civil or administrative remedies or assigning him to a pretrial diversion program. ${ }^{42}$

When deciding whether to bring charges, prosecutors may not discriminate on the basis of the race, religion, beliefs, sex, national origin, or political affiliation of an accused, except when these characteristics are a defined element of the crime. ${ }^{43}$ For instance, the race of the offender and his victim might be appropriate considerations in determining whether to prosecute a civil rights violation. ${ }^{44}$ Finally, the prosecutor cannot consider her personal feelings about the accused, the victim, or the acquaintances of the accused, or the effect of prosecuting on the attorney's personal or

39 Id. 9-27.230. Regarding culpability, the comment clarifies that "if for example, the person was a relatively minor participant in a criminal enterprise conducted by others, or his/her motive was worthy, and no other circumstances require prosecution, the prosecutor might reasonably conclude that some course other than prosecution would be appropriate." Id. 9-27.230 cmt. 4 . The comment also adds another consideration, "The Person's Personal Circumstances," which permits prosecutors deciding whether to bring charges to consider the age and health of the accused as potential mitigating factors, or the person's abuse of a position of trust as a potential aggravating factor. $I d$. 9-27.230 cmt. 7 .

$40 \quad$ Id. 9-27.240

41 See id. 9-27.250

42 Pretrial diversion programs "divert certain offenders from traditional criminal justice processing into a program of supervision and services administered by the U.S. Probation Service." Id. 9-22.000.

$43 \quad$ Id. $9-27.260$

44 See id. 9-27.260 cmt. 
professional life. ${ }^{45}$ To ensure that any such inappropriate considerations do not affect prosecutors' charging decisions, they must record their reasons to prosecute or to decline prosecution. ${ }^{46}$

While prosecutors "should resist" departures forbidden by the U.S. Sentencing Guidelines, ${ }^{47}$ the Manual does not require them to oppose departures that the guidelines permit. ${ }^{48}$ Prosecutors should make sentencing recommendations when required to do so by the terms of a plea agreement or in "unusual cases" where there is "good reason to anticipate the imposition of a sanction that would be unfair to the defendant or inadequate in terms of society's needs ... ."49 In such a case, the "public interest warrants an expression of the government's view concerning the appropriate sentence." 50 Thus, even if the court has not asked for her opinion, a prosecutor might either recommend probation where "imprisonment plainly would be inappropriate" or recommend imprisonment rather than probation if that would be the more appropriate punishment. ${ }^{51}$ Prosecutors must bear in mind, however, that the "primary responsibility for sentencing lies with the judiciary," and, therefore, they should not routinely make sentencing recommendations. ${ }^{52}$

The Manuel is clear that it is meant as a guide to the exercise of discretion, and does not mandate any particular result: "Although these materials are designed to promote consistency in the application of

45 Id.

46 See id. 9-27.270. A prosecutor's reasons to prosecute or decline prosecuting, however, are not generally discoverable. To prove selective prosecution, a defendant must show that the prosecutorial policy had a discriminatory effect and was motivated by a discriminatory purpose. See United States v. Armstrong, 517 U.S. 456, 465 (1996). To gain access to the files necessary to prove the discriminatory purpose, the defendant must first present "some evidence tending to show the existence of the essential elements of' a selective prosecution claim," or make "a credible showing of different treatment of similarly situated persons." Id. at 470 (quoting United States v. Berrios, 501 F.2d 1207, 1211 (2d Cir. 1974)).

47 See id. 9-27.745.

48 Id. $9-27.730 \mathrm{cmt}$.

49 ld. $9-27.730$

$50 \quad$ ld. 9-27.730

51 Id. 9-27.730 cmt.

52 ld. 
Federal criminal laws, they are not intended to produce rigid uniformity among Federal prosecutors in all areas of the country at the expense of the fair administration of justice." ${ }^{3}$ This language mirrors Robert $\mathrm{H}$. Jackson's 1940 exhortations to the U.S. Attorneys assembled in the Great Hall of the Department of Justice: ${ }^{54}$

Your responsibility in your several districts for law enforcement and for its methods cannot be wholly surrendered to Washington, and ought not to be assumed by a centralized Department of Justice. It is an unusual and rare instance in which the local District Attorney should be superseded in the handling of litigation, except where he requests help of Washington. ${ }^{55}$

\section{Model Standards: ABA Standards for Criminal Justice Relating to the Prosecution Function}

The American Bar Association Standards for Criminal Justice Relating to the Prosecution Function ${ }^{56}$ (ABA Standards) also grant broad discretion for prosecutors in their charging decisions. While the Department of Justice has not adopted the ABA Standards as official policy, the Manual recognizes that courts look to them to determine prosecutors' ethical obligations and recommends that prosecutors become familiar with them. ${ }^{57}$ The ABA Standards describe prosecutors as "administrators of justice," "advocates," and "officers of the court," and emphasize that "the duty of the prosecutor is to seek justice, not merely to convict." 59 They also encourage prosecutors to be reformers, actively working to remedy "inadequacies or injustices in the substantive

Id. 9-27.140 cmt. (emphasis added).

Larry D. Thompson \& Elizabeth Barry Johnson, Money Laundering: Business Beware, 44 Ala. L. Rev. 703, 722 (1993).

Jackson, supra note 7 , at 3-4.

ABA Standards, supra note 5 .

See Manual, supra note 30, 9-2.101.

Id. 3-1.2(b).

Id. 3-1.2(c). 
or procedural law."60 Furthermore, prosecutors are subject to the laws, ethical codes, and traditions governing their jurisdictions. ${ }^{61}$

Moreover, the ABA Standards recommend that prosecutors' offices promulgate "general policies to guide the exercise of prosecutorial discretion" so as to "achieve a fair, efficient, and effective enforcement of the criminal law." 62 The ABA Standards require prosecutors not to misrepresent factual or legal matters to the court, ${ }^{63}$ and impose upon them an affirmative obligation to disclose legal authority that they know is "directly adverse" to their position even if defense counsel has not made the tribunal aware of such authority. ${ }^{64}$

The ABA Standards additionally suggest that the prosecutor consult with victims before deciding whether to prosecute the accused, pursue a plea bargain, or dismiss charges already filed against the defendant. ${ }^{65}$ Nevertheless, the prosecutor retains the primary responsibility to decide whether to institute and maintain criminal proceedings against a defendant. ${ }^{66}$ In making this decision, she should consider available noncriminal dispositions even if there is probable cause to press criminal charges - particularly if the defendant is a first-time offender and the offense is minor. ${ }^{67}$ Even when the prosecutor chooses to bring charges, however, she "is not obliged to present all charges which the evidence might support." 68 Factors she should consider in exercising this discretion include "the disproportion of the authorized punishment in relation to the particular offense or the offender," 69 her reasonable doubt about the guilt

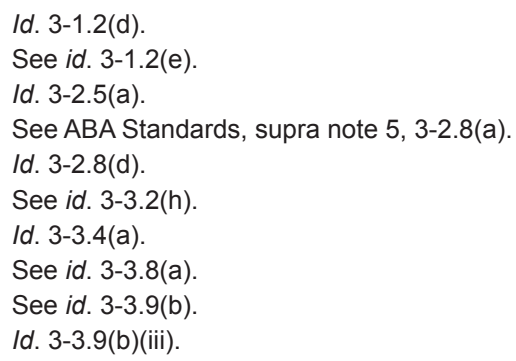


of the accused, ${ }^{70}$ and the amount of harm caused by the offense..$^{71}$ The prosecutor should not bring more or greater charges "than can reasonably be supported with evidence at trial or than are necessary to fairly reflect the gravity of the offense."72 Furthermore, supervisors should not compel prosecution when there is reasonable doubt about the guilt of the accused. ${ }^{73}$ Finally, the ABA Standards encourage prosecutors to make themselves available for individual plea discussions, and to announce a general willingness to dispose of charges though plea bargains. ${ }^{74}$

Once at trial, the prosecutor has a duty as an officer of the court to "strictly adhere to codes of professionalism." If the defendant is convicted, "the prosecutor should not make the severity of sentences the index of ... her effectiveness." ${ }^{\text {"I }}$ In addition, she should provide the court with any information relevant to the sentence for the presentence report ${ }^{77}$ and inform the court and defense counsel of all unprivileged mitigating information of which she is aware, either at or before sentencing. ${ }^{78}$ If the prosecutor chooses to comment on the sentence, "she should seek to assure that a fair and informed judgment is made on the sentence and to avoid unfair sentence disparities."79

See id. 3-3.9(b)(i).

71 See id. 3-3.9(b)(ii). According to the ABA, other factors the prosecutor should consider include the motives of the complainant, the victim's willingness to testify, the defendant's cooperation in apprehending or convicting others, and the possibility of prosecution in another jurisdiction. See id. 3-3.9(b)(iv)-(vii).

72 Id. 3-3.9(f).

73 Id. 3-3.9(c).

74 See id. 3-4.1(a).

75 Id. 3-5.2(a).

76 Id. 3-6.1(a).

77 Id. 3-6.2(a).

78 Id. 3-6.2(b).

79 Id. 3-6.1(a). 


\section{Ethical Rules}

\subsection{ABA Model Rules of Professional Conduct}

The Model Rules of Professional Conduct recognize that prosecutors are not only advocates, but also "ministers of justice" with a responsibility to ensure that the defendant receives "procedural justice" and that sufficient evidence supports a guilty verdict. ${ }^{80}$ While responsibility may differ by jurisdiction, many states have adopted the ABA Standards of Criminal Justice Relating to the Prosecution Function. ${ }^{81}$ Thus, prosecutors must refrain from prosecuting charges not supported by probable cause, ${ }^{82}$ disclose all evidence negating the defendant's guilt or mitigating the offense, and provide all unprivileged mitigating information to both the court and defense counsel at sentencing. ${ }^{83}$ Furthermore, as with all lawyers, if a prosecutor "knows that a client expects assistance not permitted by the rules of professional conduct or other law, the lawyer shall consult with the client regarding the relevant limitations on the lawyer's conduct." 84

\subsection{ABA Model Code of Professional Responsibility}

The ABA Model Code of Professional Responsibility-which has been largely superseded by the Model Rules, above—set aspirational

80 See Model Rules of Prof'l Conduct R. 3.8 cmt. 1 (2001) [hereinafter Model Rules].

81 See id.

82 See Model Rules R. 3.8(a).

83 See id. R. 3.8(d). Other prosecutorial responsibilities include "making reasonable efforts to assure" that the defendant knows he has the right to counsel and has been given the opportunity to obtain counsel. Id. R. 3.8(b). The Rules also require prosecutors to refrain from seeking a waiver of important pretrial rights from an unrepresented defendant, avoid subpoenaing lawyers regarding client behavior except in certain circumstances, and refrain from making extrajudicial comments that might prejudice the defendant. See id. R. 3.8(c), (e), (f).

84 See id. R. 1.2(e); cf. Model Rules, supra note 80, R. 1.2 (abrogating Rule 1.2(e) and, instead, instructing in Rule 1.4(a)(5) that "[a] lawyer shall consult with the client about any relevant limitation on the lawyer's conduct when the lawyer knows that the client expects assistance not permitted by the Rules of Professional Conduct or other law"). A government attorney's client may be "an agency official, the agency itself, the government as a whole, or the 'public interest." Catherine J. Lanctot, The Duty of Zealous Advocacy and the Ethics of the Federal Government Lawyer: The Three Hardest Questions, 64 S. Cal. L. Rev. 951, 955 (1991). 
standards called "Ethical Considerations" and binding "Disciplinary Rules." ${ }^{5}$ The Code recognizes that "the responsibilities of a lawyer may vary" depending on the particular obligations she may have, including those stemming from "service as a public prosecutor." 86

The Ethical Considerations state that a prosecutor's "duty is to seek justice, not merely to convict." 87 Similarly, a lawyer's duty to represent her client zealously does not diminish her obligation to "avoid the infliction of needless harm" and treat others involved in the legal process with respect. ${ }^{88}$ Thus, she should use restraint when exercising discretionary powers ${ }^{89}$ and "refrain from instituting or continuing litigation that is obviously unfair." ${ }^{0}$ If a prosecutor has no discretionary power, she should recommend against continuing unfair litigation. ${ }^{91}$

The Disciplinary Rules constrain a prosecutor's discretion in less ambitious-but more prescriptive-terms and require a prosecutor not to institute charges when she "knows or it is obvious that the charges are not supported by probable cause." 92 Furthermore, she must disclose to the defendant or defense counsel any exculpatory evidence and any evidence that mitigates the degree of the offense or lessens the defendant's punishment. ${ }^{93}$

See Frank S. Bloch et al., Filling in the 'Larger Puzzle': Clinical Scholarship in the Wake of The Lawyering Process, 10 Clinical L. Rev. 221, 228 n.25 (2003) (explaining that attorneys "were supposed to strive to follow the ethical considerations, but they were not considered binding" (quoting John S. Dzienkowski, Professional Responsibility Standards, Rules and Statutes: 2003-04 Abridged Ed. 553 (2003))). But see, e.g., Freeport-McMoRAN Oil \& Gas Co. v. Fed. Energy Reg. Comm'n, 962 F.2d 45, 47 (D.C. Cir. 1992) (invoking Model Code of Professional Responsibility EC 7-14 to scold a government civil lawyer who suggested that the government lawyers had no obligations beyond those of private attorneys). See Model Code of Prof'l Responsibility EC 7-11 (1981).

87 Id. EC 7-13.

88 Id. EC 7-10.

89 See $i d$.

90 Id. EC 7-14.

91 Id.

92 Id. DR 7-103(A).

93 Id. DR 7-103(B). 
Finally, ABA Model Code Ethical Considerations counsel lawyers to strive to improve the legal system. ${ }^{94}$ Because laws should be "just, understandable, and responsive to the needs of society," ${ }^{5}$ lawyers should participate in the legislative process to improve the system "without regard to the general interests and desires of clients or former clients."96

\section{Conclusion}

Prosecutors are uniquely situated to "seek justice" because they are familiar with the aggravating and mitigating circumstances of the cases they control. And as the U.S. Supreme Court recognized, "we must have assurance that those who would wield [prosecutorial] power will be guided solely by their sense of public responsibility for the attainment of justice." 97 Prosecutors' discretion in the United States is also guided by ethical precepts handed down by the common law, promulgated in the Manual, ${ }^{98}$ and passed by the American Bar Association. Each of these sources generally afford prosecutors a wide discretion to make decisions about who to prosecute, what charges to file, and whether to engage in plea negotiation with a defendant-including whether to allow a defendant to plead guilty to lesser charges. That discretion both empowers individual prosecutors to seek justice in their cases and

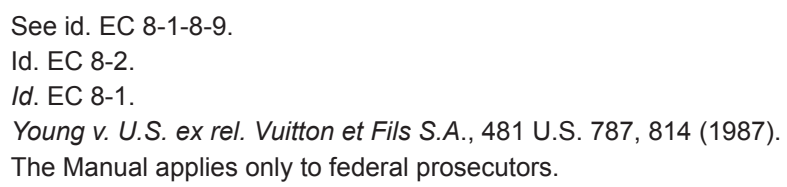


increases the efficiency in a system where many defendants agree to plead guilty.

\section{References}

ABA STANDARDS RELATING TO THE ADMINISTRATION OF CRIMINAL JUSTICE. The Prosecution Function. 1992. [hereinafter ABA Standards]. Available at: <http://www.americanbar.org/ publications/criminal_justice_section_archive/crimjust_standards_ pfunc_blk.html>.Last visited: sept. 22016.

Chris Smith, Mr. Comey Goes to Washington, N.Y. Mag., Oct. 20, 2003, available at: <http://nymag.com/nymetro/news/politics/n_9353/>. Last visited: mar. 19, 2004.

JACKSON, Robert H. The Federal Prosecutor. Journal of Criminal Law \& Criminology, Chicago, v. 31, n. 1, 1940, p. 3-6 .

United States ex rel. Green v. Peters, Nos. 93 C 7300, 93 C 5671, 93 C 5672, 93 C 5673, 1994 WL 8258, at 6 n.3 (N.D. III. Jan. 8, 1994).

People v. O’Neill, 379 N.Y.S.2d 244, 249 (1975)

UNITED STATES OF AMERICA. Supreme Court. Berger v. United States, 295 U.S. 78, 88, 1935. Availeble at: < https://supreme.justia. com/cases/federal/us/295/78/case.html>. Last visited: sept. 132016

Young v. United States ex rel. Vuitton et Fils S.A. 481 U.S. 787, 813 (1987).

Recebido em: 13/10/2016

Aprovado em: 19/11/2016 